\title{
JOURNAL OF MEDICAL RESEARCH
}

Edited by THE DIRECTOR-GENERAL, INDIAN MEDICAL SERVICE, THE PUBLIC HEALTH COMMISSIONER WITH THE GOVERNMENT OF INDIA, and THE DIRECTOR, CENTRAL RESEARCH INSTITUTE, in collaboration with LEADING AUTHORITIES ON TROPICAL. MEDICINE. The Indian Journal of Medical Research is published quarterly. Each number contains about 200 pages and is illustrated with Plates in Colour and Half-tone and with Diagrams and Charts, and is the only medium publishing the results of the best medical research work being carried on by leading scientific medical men in India and the East.

\section{THACKER, SPINK \& CO. \\ (P.O. BOX 54) LONDON AGENTS: W. Thacker \& Co., 2, Creed Lane, E.C. 4.}

CALCUTTA

\section{The Comparative Physiology of Internal-Secretion}

By LANCELOT T. HOGBEN, M.A. (Cantab.), D.Sc. (Lond.)

With 37 illustrations. Demy 8vo. 10s. $6 \mathrm{~d}$. net

Cambridge. Comparative Physiology

This is the third volume of the new series dealing with comparative physiology, which the Cambridge University Press has recently started.

The Quarterly Journal of Medicine Edited by
T. R. ELLIOTT
W. HALE-WHITE
F. R. FRASER
R. HUTCHISON
A. E. GARROD
H. D. ROLLESTON

with the help of

J. Hill Abram

Byrom Bramwell John Cowan

David Drummond

T. Wardrop Griffith

G. Lovell Gulland
Arthur J. Hall

Gordon Holmes

Arthur F. Hurst

J. A. Lindsay

H. Maclean

George R. Murray
J. A. Nixon

R. W. Philip

E. P. Poulton

E. I. Spriggs

A. M. Stalker

R. Stockman

SINGLE NUMBERS 10 s. $6 d$. NET EACH

VOLUMES - - 45s. NET

SUBSCRIPTION - 35s. PER ANNUM

\section{OXFORD UNIVERSITY PRESS HUMPHREY MILFORD, AMEN HOUSE, LONDON, E.C.4}




\section{CONTENTS}

\section{(All rights reserved)}

Kingsbury, A. Neave. The Serum Prophylaxis of Measles. (With an Introductory Note by Sir Malcolm Watson, M.D., LL.D., D.P.H.) (With 6 Figures)

KrIGLer, I. J. Study on the Epidemiology of Typhoid Fever. (With 5 Charts). . . . . . . .

HARE, J. G. and TATE, P. On the Fungi causing Ringworm in Children attending London County Council Schools. . . . . .

Writrams, R. Stennouse, and Hoy, W. A. Tubercle Bacilli in the Faeces of apparently healthy Cows

Nutrant, Zeria. The Causes of the Physical Degeneracy of Mexican Indians after the Spanish Conquest as set forth by Mexican In. formants in 1580 . . . . . . . . . .

Eckrer, E. E. and Rmington, C. A Preliminary Study of the Chemical Nature of the Toxic Substances produced by the Salmonells Group of Organisms .

Forbes, J. Grahas. Diphtheria prevalence in Hampstead and the Need for its Prevention. (With 1 Map, 2 Graphs and 3 Charts) . .

Crutcrshank, Robert. The Weil-Felix Reaction in Typhus Fever. (With 1 Chart)

Frmericha, L. S., Freudenthat, P., Gudjonnsson, S., Johansean, G. and SorovBye, N. Refection, a Transmissible Change in the Intestinal Content, enabling Rats to grow and thrive without Vitamin B in the Food. (With 10 Charts)

Roscoe, Mnrgaret Honora. Spontaneous Cures in Rats reared upon a Diet devoid of Vitamin B and Antineuritic Vitamin. .

Assis, A. DE. On Proteus pseudovaleriae and its Occurrence in Man . 108

The Journal of Hygiene is issued as material accumulates. A volume containing four numbers is issued annually in paper covers at the following net prices:

Volumes I-III (1901-3). 17s. 6d.

VolumesIV-XVI(1904-18), exceptingVol.VI, no. 4, Plague number. $25 s$. Volume XVII (1918). 31s.

Volumes XVIII-XXV (1919-1926). 42s. each.

Quotations can be given for buckram binding cases and for binding subseribers' sets; also for bound copies of back volumes.

Papers for publication may be sent to Prof. Gro. H. F. Nuttall, F.R.S., Longfield, Madingley Road, Cambridge, or to the associate Editors. Other communications should be addressed to the University Press, Cambridge.

Papers forwarded to the Editors for publication are understood to be offered to The Journal of Hygiene alone, unless the contrary is stated.

Contributors receive fifty copies of their papers free. Additional copies may be had at cost price: these should be ordered when the final proof is returned.

The subscription price is $£ 2.2 s$. per volume (post-free), payable in advance; single numbers $12 s .6 \mathrm{~d}$. net. Subscriptions may be sent to any Bookseller, or to The Cambridge University Press, Fetter Lane, London, E.C. 4.

The Cambridge University Press has appointed the University of Chicago Press agents for the sale of The Journal of Hygiene in the United States of America and has authorised them to charge the following prices: Subscription $\$ 10.00$ per volume; single numbers, $\$ 3.00$ each.

Plague Numbers, Vol. VI. no. 4 (out of print), Vol. VII. nos. 3 and 6 , and Vol. VIII. no. 2, Vol. X. no. 3, Price $6 \mathrm{~s}$. net each.

A series of Plague Supplements has been issued; the first four of these contain Reports VI-IX on Plague Investigations in India. They are, in pagination, completely independent of the Journal although subscribers to the latter receive copies without extra cost. Price of Plague supplements, i. and ii. 7s. net each; iii. 10s. net; iv. and v. 7s. net each. Plague Supplements i, ii, iii can also be supplied bound in buckram, price 20s. net. 